\title{
The Need for Interactive Technology in Brunei Museum: An Empirical Study of Visitor Experience
}

Fahmi Ibrahim, Nurfadhlina M Zainin, Salamiah A Jamal

To Link this Article: http://dx.doi.org/10.6007/IJARBSS/v11-i16/11227

DOI:10.6007/IJARBSS/v11-i16/11227

Received: 12 July 2021, Revised: 17 August 2021, Accepted: 30 August 2021

Published Online: 22 September 2021

In-Text Citation: (Ibrahim et al., 2021)

To Cite this Article: Ibrahim, F., Zainin, N. M., \& Jamal, S. A. (2021). The Need for Interactive Technology in Brunei Museum: An Empirical Study of Visitor Experience. International Journal of Academic Research in Business and Social Sciences, 11(16), 180-198.

\section{Copyright: (C) 2021 The Author(s)}

Published by Human Resource Management Academic Research Society (www.hrmars.com)

This article is published under the Creative Commons Attribution (CC BY 4.0) license. Anyone may reproduce, distribute, translate and create derivative works of this article (for both commercial and non-commercial purposes), subject to full attribution to the original publication and authors. The full terms of this license may be seen at: http://creativecommons.org/licences/by/4.0/legalcode

Special Issue Title: Contemporary Issues in Tourism and Hospitality industry, 2021, Pg. 180 - 198 


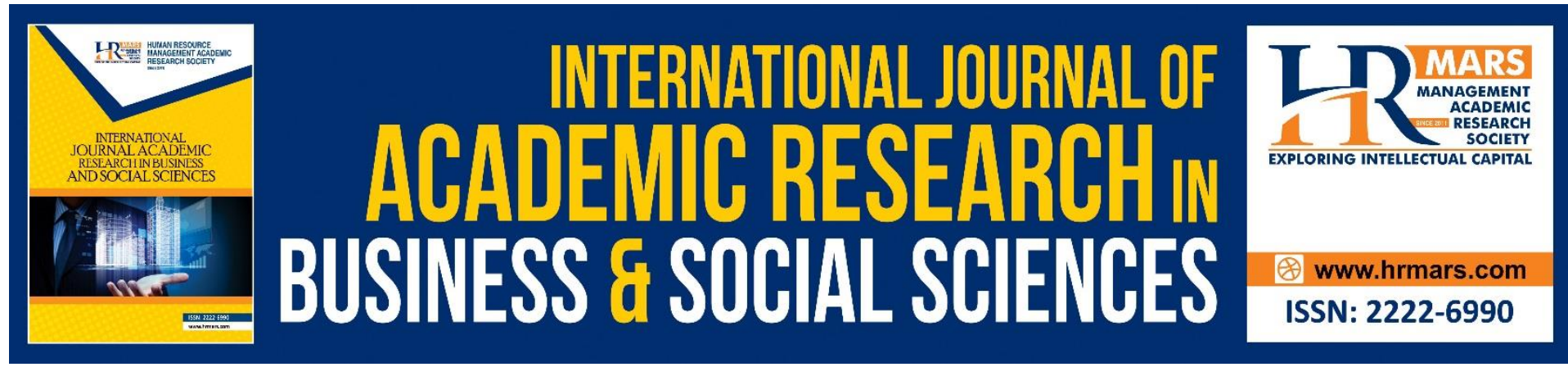

\title{
The Need for Interactive Technology in Brunei Museum: An Empirical Study of Visitor Experience
}

\author{
Fahmi Ibrahim ${ }^{1}$, Nurfadhlina M Zainin ${ }^{1}$, Salamiah A Jamal ${ }^{2}$
}

${ }^{1}$ School of Business, Universiti Teknologi Brunei, Brunei Darussalam, ${ }^{2}$ Faculty of Hospitality and Tourism Management, Universiti Teknologi MARA, Malaysia

Email: salam383@uitm.edu.my

\begin{abstract}
This article aims to understand visitor experience in Brunei Museum and gauge visitors' views on interactive technology in museums with regards to satisfaction. Based on a sample of 129 respondents, a quantitative study was conducted, and the findings conclude that contemporary museum initiatives have a minimal impact on visitors' levels of satisfaction. With only the aspects of meaningful experience and learning outcomes being successfully practised, visitors perceived Brunei Museum as old-fashioned and offering little by way of interactive engagement. The need for interactive exhibitions with passive and active technologies should positively impact the visitor's social experience. This article contributes to the literature addressing the social experience phenomenon in a cultural, educational, and touristic context. It also provides important implications for managers involved in the design and management of technology-empowered tourism experiences.
\end{abstract}

Keywords: Museum, Interactive technology, Visitor experience, Satisfaction, Tourism

\section{Introduction}

Museums originate from the need to acquire, conserve, research, communicate, and exhibit material evidence of human beings and the environment for the benefit of the public (Sökmen et al., 2020). They operate to gather and preserve objects that are vital and valuable to the nation and represent the country's heritage. Thus, museums nowadays are one of the popular sites for cultural heritage tourism, on top of which they also fulfil the traditional purpose of education and leisure. Previous studies have examined visitor management strategies (Gilmore \& Rentschler, 2002; Scoffield \& Liu, 2014) by discovering how museums can compete with other leisure and entertainment sectors (Davidson \& Sibley, 2011; Rentschler \& Gilmore, 2002) and determining appropriate marketing strategies (Cerquetti, 2016; Komarac et al., 2017; Pulh \& Mencarelli, 2015).

However, with the vast number of visitors from different age categories, museums often fall short in serving visitors' needs due to a failure to utilise the latest interactive technology, and are thus unable to implement personalised approaches for everyone. Although the emergence of interactive technology has enabled museums to enrich visitor experience, there has been little research as to whether museums use these conditions to tailor their offerings towards meeting visitors' evolving expectations and demands (Taheri et al., 2016). Therefore, the 
current study aims to understand visitor experience under the existing technology in Brunei Museum and visitors' views regarding future interactive technology.

The findings of this study are likely to contribute significantly to museum management and strategy by furthering the understanding of museums and their technology. While many studies have examined museum visitors' behaviour (Jafari et al., 2013; Sökmen et al., 2020), visitor experience through the lens of technology conditions, specifically in Brunei Museum, has not received due attention (Ibrahim \& Zainin, 2021). This study will fill this research gap primarily by focusing on the contemporary conditions employed by influential museums. Furthermore, the study results are expected to help museums navigate the latest technology requirements to gain a competitive edge in the marketplace.

\section{Literature Review}

Technology has become an integral part of everyday life. With its immense presence in the world, it is not possible to neglect the trend of technology integration, especially when it offers plentiful benefits to its users. In most organisations, the adoption of technology has been widespread, particularly in the education sector, in which it fulfils the main function of technology, that is, to encourage interaction. Assimilating technology produces diverse learning experiences which, in turn, makes the learning process an enjoyable one, and which is embraced by most of its users (Budhwar, 2017). Infusing technology is not only applicable to schools, but to museums as well. Nowadays, having interactive exhibitions is an important aspect for museum professionals, whereby they align with their intention to convey the museum's contents as effectively as possible. Despite most researchers' emphasis on the use of multimedia only in science museums, history museums are no exception to this trend (Adam et al., 2005). Some modern museums are now adopting digital technologies, such as virtual reality and touchscreen, so that people can better comprehend and obtain more knowledge about the objects being presented (Ahlamo, 2013). O'Mahony (2013) suggested museums should employ technology use to grow and gain more visitors. Thus, this new concept of the museum is increasingly favoured by the younger generation. Apparently, technology helps museum sustainability in the long run. Since technology is a major component of global development, it enables museums to keep pace across the generations. By implementing technology, it may positively affect museum experience. For instance, the presentation of artefacts would become more attractive and expressive (Pop \& Borza, 2016).

Dependence on artefacts alone would not be sufficient to satisfy visitors, as objects are only exhibited as evidence (Thomas, 1999). Thus, the inclusion of interactive multimedia will certainly enhance visitor experience. Exhibitions would be more enjoyable and engaging, while learning about the museum's contents would become efficient. When museum professionals understand their visitors' individual desires, museums will fare much better because they will guide them to devise suitable technology before applying it. At the same time, technology use will contribute to creating an immersive environment that fosters the emotions and meaningful interactions of visitors by enabling them to experience the museum collections (Vaz et al., 2018). As a result, visitors will become more satisfied with their visitor experience and, thus, lead to future revisits. Past researchers have constantly proven this theory whereby technology has helped institutions attract more customers. Indeed, when customers' needs are fulfilled, it will certainly make them come back again for another trip. This process happens in museums. The more satisfied visitors are with their engagement, the more likely they are to revisit. Certainly, museums serve the public as cultural and educational institutions of the nation. However, when it comes to value or knowledge transmission, they become rather ineffective. 
As Hellgren (2015) mentioned, museums' premise to preserve and present artefacts no longer holds visitor interest, especially in today's world. As people nowadays crave stimulating experiences and attempt to gain meaningful connections, museums are now encouraged to alter their traditional methods of engagement and traditional approaches to exhibition design by implementing interactive technologies. With the aid of technology, museums are able to enhance the process of visitor-exhibit interactivity which, subsequently, increases visitors' experiences and their degree of satisfaction (Stogner, 2011). Lehn and Heath (2005) highlighted the essentiality of technology in transforming the museum environment to improve the museum experience and, at the same time, turn visitors from passive to active participants. As declared by Stogner (2009), interactive technologies act as enablers that transform museums from performing "expert-centric" to "visitor-centric" services. Among many of the past kinds of literature, technology has become the focus in trying to accommodate and improve the services in museums. Several findings have shown that media technology is indeed useful in improving the learning experience of visitors, while some findings have failed to prove so.

\section{Methodology}

Quantitative research methods incorporate the systematic collection, organisation, and interpretation of numerical material derived from surveys and questionnaires (Denzin \& Lincoln, 2011). Therefore, an exploratory approach adopting a quantitative research method using selfadministered questionnaires was decided to be most suitable for the purposes of this study. Three local museums were included in the study under the assumption that they behave similarly in terms of management and marketing, since they are located in the same BruneiMuara district: Royal Regalia Museum, Malay Technology Museum, and Brunei Maritime Museum. These museums are known to be the most popularly visited ones, among others, revealing themselves to be part of tourists' destinations and the go-to places for locals, especially for educational visits. This study employed a non-probability sampling technique and purposive sampling based on visitors' opinions. These respondents included visitors who have visited any of the three museums at least once within the past 12 months. To collect their opinions, a link to an online form, accessed via Google Forms, was sent to the respondents between 3rd March and 3rd May, 2020. A total of 129 usable responses were collected during this period.

\section{Data Collection}

This study used self-administered questionnaires to collect data. To finalise the data collection instrument, two experts in quantitative and business research, and two representatives of museums, were approached, and the question form was re-evaluated. Finally, 63 questions about respondents' experiences were included and arranged into three sections. The first section concerns brief information on the museum trips. The second section asks respondents their opinions on the technology used in the museums. In this section, the questions asked attempted to understand the two aspects of Multimedia Guide Scale (General Usability and the Quality Interaction). Finally, the respondents were asked to rate their overall museum experience with reference to the aspects of Museum Experience Scale (Engagement, Emotional Connection, Meaningful Experience and Learning Outcomes). This section aims to uncover respondents' thoughts about museum exhibition design and their revisit intentions. 


\section{Data Analysis}

The data were analysed descriptively. Descriptive analysis helps to develop a framework for the organisation and interpretation of the data. This analysis is comprised of three steps: data processing according to a descriptive statistic, identification of findings, and interpretation of findings. The statistics from the survey were processed through descriptive statistics that were useful in providing an overall picture of the responses. Since the quantitative approach mostly used a 5-point Likert scale, the tendency for participants to select 'neutral' was high. Therefore, when measuring the value from it, the use central tendency mean was employed to gain more precise data (Hardy, 2004).

\section{Result and Analysis}

The number of local respondents in this sample was relatively high (99.2\%). Analysis of the respondents' purpose of visit clearly showed that the rationale was mostly sightseeing (23.3\%), followed by educational trips (15.6\%). According to them, the museum that made a great impression was the Royal Regalia Museum (53.5\%), while Brunei Maritime Museum (14.7\%) was accounted to be the least impressive one. Most of the respondents have known museums through educational activities and word-of-mouth, including stories from friends, family, and relatives. As opposed to this, social media was the second last medium recognised by the public to discover the museums.

\section{Technology Use in Museums}

As Brunei museums are yet to acquire the complete line-up of the latest technology, this section aims to assess visitors' level of agreement towards the usefulness of technology at the exhibition in terms of general usability and their quality of interaction with the guide. The focus was on touchscreen and kiosks for tangible museum collections, while intangible collections were presented through audio-visual guides, such as sound effects and videos. Fourteen questions were constructed in measuring the aspects of Multimedia Guide Scale, and two (2) questions involved acquiring visitors' suggestions on the use of technology in museums. Besides getting visitors' feedback on the current museum settings, the purpose was to discover the types of interactive technology that contributed to visitors' satisfaction.

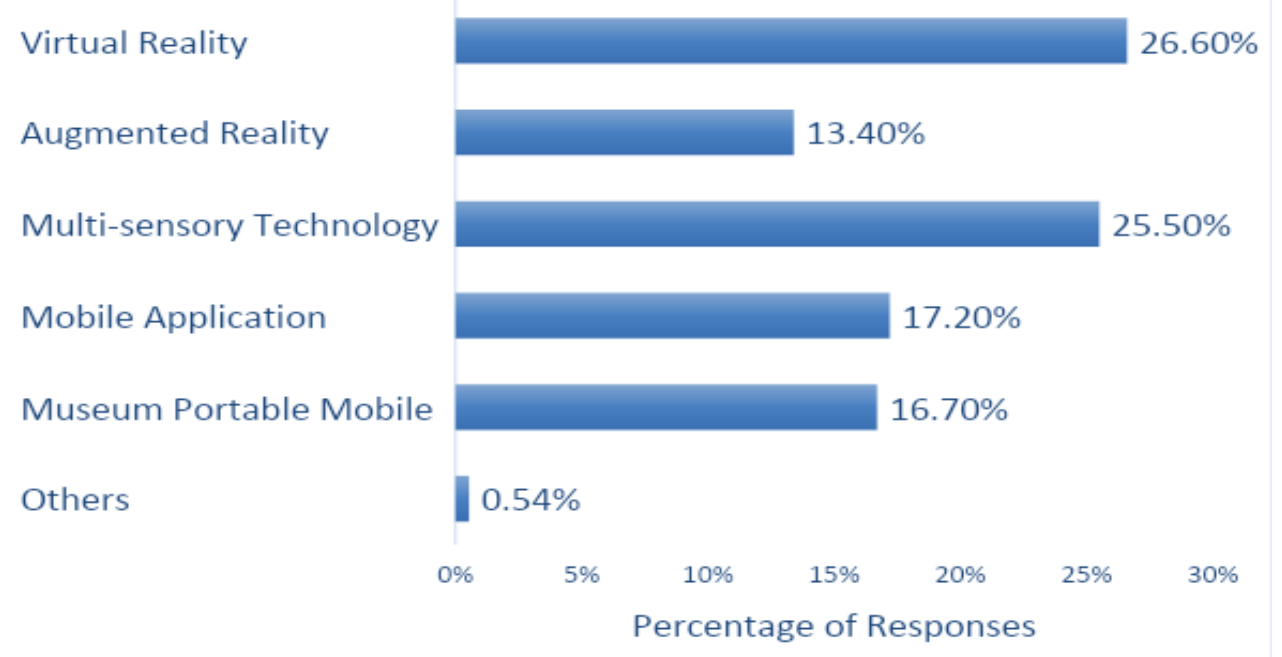

Figure 1. Types of advanced technology suggested by visitors for the museums. 
Figure 1 shows virtual reality (26.6\%) as the highest rated technology suggested by visitors, followed by multi-sensory technology (25.5\%) and mobile application (17.2\%). The findings prove that nowadays visitors to museums are searching for fragmented moments in liquid time. This fact also highlights visitors' desire to experience a combination of social, recreational, and educational activities simultaneously, as Davidson and Sibley (2011) suggested. Brunei museums have great potential in exposing more of its intangible heritage by creating real-life experiences through virtual reality and multi-sensory technology. This experience should be further enhanced via mobile applications for personalised usability. Meanwhile, augmented reality $(13.4 \%)$ received less responses due to the nature of augmented reality where it is mostly used to show fragile artefacts or the unavailability of original items. This is not the case in Brunei museums where all original artefacts are available and well preserved.

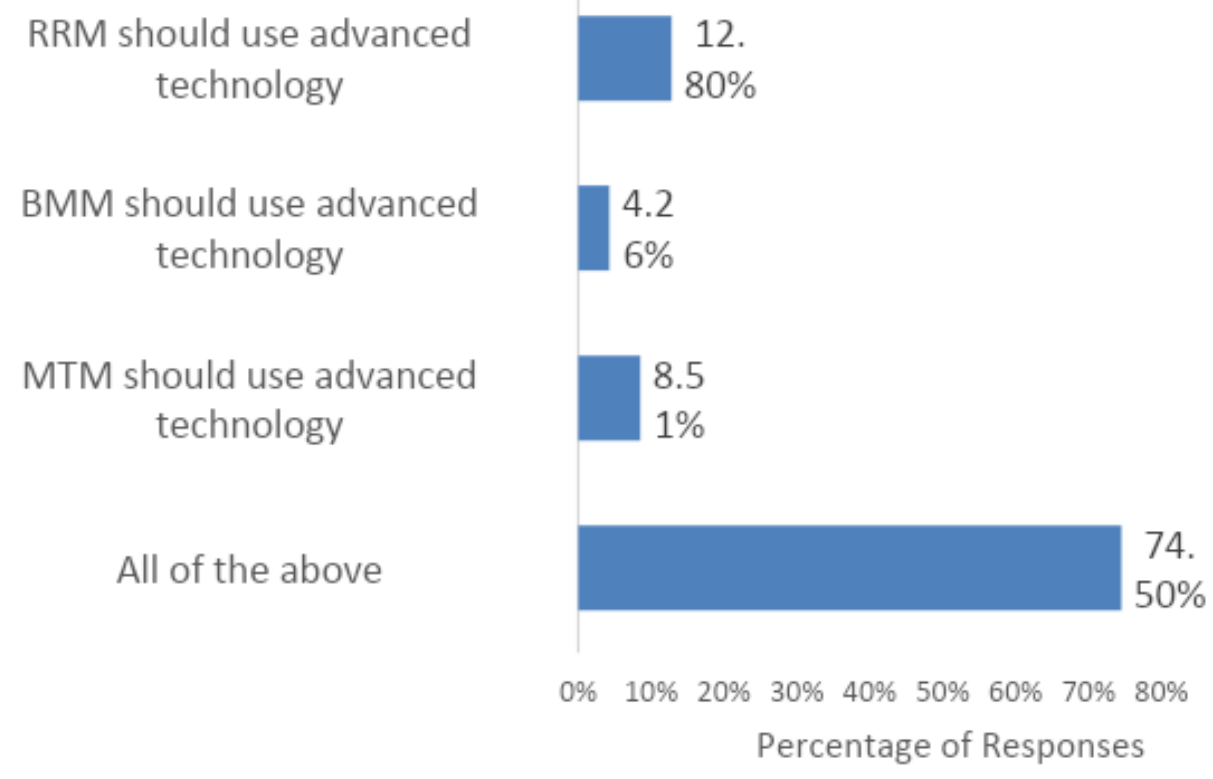

Figure 2. Suggestion on the use of technology in the museums.

Figure 2 confirms the lack of advanced technology usage in Brunei museums. The majority of the respondents (74.5\%) voted that all three museums should adopt the latest technology for an improved visitor experience. This indicates that technology, such as virtual reality and multisensory technology, would better expose the collections in all three museums. Traditional approaches in presenting artefacts are no longer as effective as they were in the past. Thus, museums are encouraged to reshape their strategy, from being old-fashioned to high-tech museums, because visitor experience is very much correlated with the use of technology (Hellgren, 2015).

\section{Multimedia Guide Scale}

Multimedia Guide Scale (MGS) helps to identify the extent to which the technologies used in the museums have played significant roles in its (i) usability and (ii) quality interaction between the visitors and the guide. Hence, the results from this section show visitors' feedback on museum settings that integrate technology into their exhibitions. However, this section limits the chances for participants who have not yet seen or used the technology in the museums to answer the questions. Thus, an instruction was given to them to which they could vote neutral 
throughout this section, as a means of ease in obtaining valid and reliable data from those who have experienced the technology provided at least once. Therefore, samples of 89 respondents were identified to have given proper answers after a thorough analysis.

\section{i.General Usability}

The scope of general usability in this study focuses on perceived usefulness, enjoyment and engagement, its efficiency, ease of use, and the intention to use. Figure 3 presents the mean score of the visitors' level of agreement towards the usability of the technology provided.

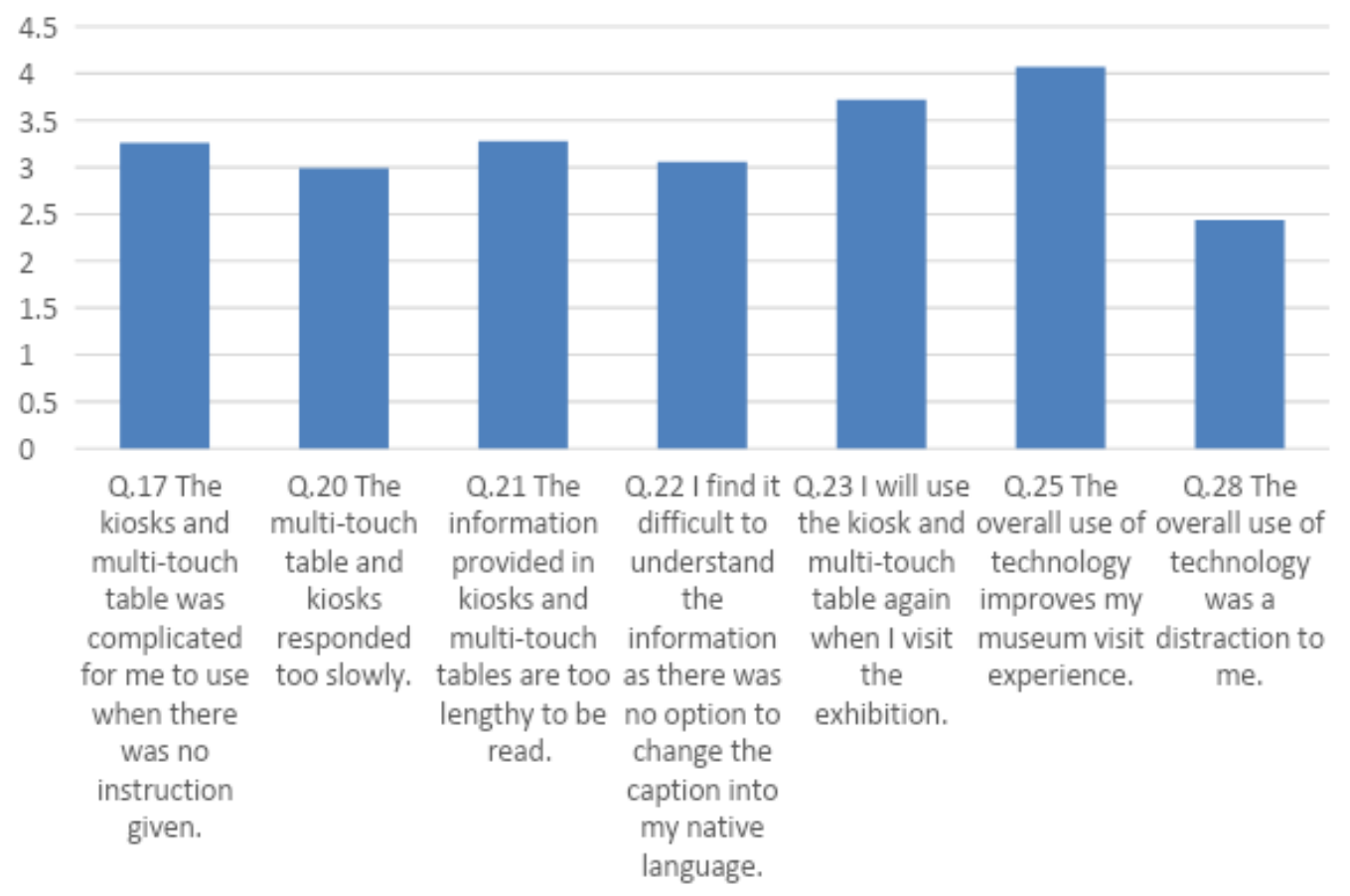

Figure 3. The mean score for the general usability of technology provided in the museums. Note: 5 -point Likert Scale (1= Strongly Disagree, 2= Disagree, $3=$ Neutral, $4=$ Agree, $5=$ Strongly Agree).

Note that Questions 17 to 22 dealt with the specific comments on the technology used in the museums, while Questions 23, 25, and 28 aimed to observe the effects of general technology on the overall visitor experience. As shown in Figure 3, Question 17 scored an average of 3.26, indicating that the respondents faced difficulties using the technology without any instruction. This could be the result of respondents being from various age ranges. Question 20, on the other hand, measured technology efficiency, which showed a mean of 2.99, indicating visitors' uncertainty towards the technology. This correlates with Question 22 as it scored another neutral (3.06) showing that visitors were again unsure about the captions presented. It could be due to the unavailability of functioning touchscreens, thus, making visitors unsure about these questions. In terms of engagement and enjoyment, some respondents agreed to Question 21, indicating the presentation of museum collections to be somewhat engaging and enjoyable for the visitors.

Most respondents agreed that the use of technology in museums will surely improve their visitor experience (Question 25), thereby resulting in the average of 2.44 to the statement, "The overall use of technology was a distraction to me." As a result, Question 23 scored a mean of 3.72 , indicating respondents' anticipation to use touchscreens and kiosks in future visits. Most 
respondents answered 'neutral' when asked about the efficiency of kiosks and multitouchscreen and the language preference for presentation of museum collections (English or Bahasa). Further analysis found that, at times, the touchscreen and kiosks were out of service, thus proving highly inconvenient. The difficulty escalates with the absence of instruction, despite the age variations of respondents. The finding is supported by Not and Petrelli (2018), highlighting that the delivery of museum contents should be engaging and, at the same time, provide visitors with multiple opportunities to experience the museum collections and share their personalised experiences with others. Stogner (2011) emphasises that museum visits do not have to be entirely educational, but should also be entertaining.

ii. Quality Interaction with the Guide

The quality gained through technology use was measured in terms of presentation of museum collections, technology's ease of use, and its ability to engage, inspire and creativity. Figure 4 shows the results on visitors' level of agreement towards their quality interaction with the technology.

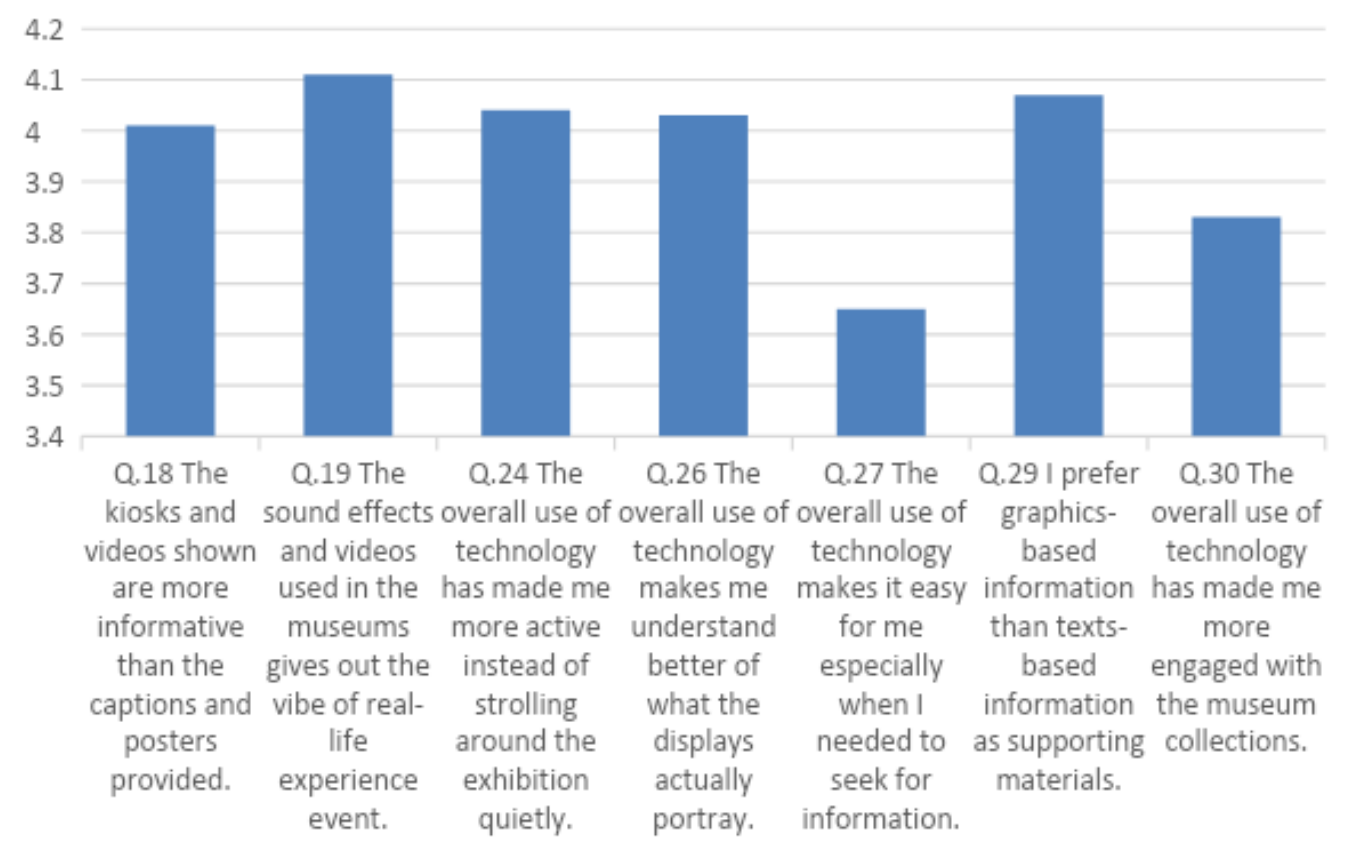

Figure 4 . The mean score for quality of interaction with the technology provided in the museums.

Note: 5-point Likert Scale (1= Strongly Disagree, 2= Disagree, 3= Neutral, 4= Agree, 5= Strongly Agree).

As shown in Figure 4, all questions scored more than an average of three, suggesting that most respondents agreed to the statements. When measuring the quality on the presentation of museum collections, most respondents agreed that technology showed more information than captions and posters. This was further approved by Question 29 whereby respondents confessed their preferences towards graphic-based displays instead of text-based materials. Many respondents were also in agreement with the statement "The overall use of technology makes me understand better" and "The overall use of technology makes it easier for visitors when they need to seek information" in Questions 26 and 27, respectively. This suggests it is evident that museum visitors in Brunei favour technology which largely involves visually 
attractive materials as a method for presenting the museum collection in as convenient and understandable manner as possible.

When discussing the quality of interaction in triggering one's engagement, creativity and inspiration, visitors agreed to Question 24, whereby technology use made them more active than passive. Some of them agreed that technology increases engagement with museum collections (Question 30). In addition, Question 19 further supported the previous statements whereby more than half of respondents agreed on the use of sound effects and videos in creating real-life experience events. Hence, giving a bigger picture, those visitors in Brunei became more engaged with the collections through technology use in museums. According to Othman (2012), technology use in museums enables visitors to experience exhibitions in a more diverse way and, at the same, enables them to choose different options according to their preferences in learning about the collections. This statement was supported by the research findings, whereby most respondents acknowledged that technology has made the quality of interaction between visitors and collections to be nearly excellent. However, in terms of usability, visitors claimed to be unsatisfied in those Brunei museums that focus heavily on being object-centric instead of visitor-centric.

In terms of usability, it was discovered that respondents agreed on the importance of quality interaction with technology with almost all statements in this section scoring an average mean of 4. This explains that, regardless of the difficulty in managing the technology, visitors are willing to use them for the sake of betterment in understanding museum collections. As Davis (1993) implied, perceived ease-of-use has minimal impact on one's attitude compared to perceived usefulness. Despite respondents claiming kiosks and touchscreens to be slightly inefficient, both displayed informative museum contents which, in turn, displayed the collections in a much more understandable manner. Moreover, utilising the audio-visual guide further improves the quality of interaction, as it provides the actual experiences of real-life events. Hashim et al. (2014) agreed to this declaration, implying that certain visual effects brought an exhibition to life to an extent which provided visitors with more experiences and excitement while engaging with the contents, thus correlating with visitors' agreement on overall technology use creating greater engagement with museum collections.

Additionally, most respondents agreed that the technology provided in the museums was capable of making visitors less passive, thus agreeing with the findings of Lehn and Heath (2005). They also admitted that, with the aid of technology, it helps visitors to gain information conveniently, indicating touchscreens and kiosks to be less burdening, and are helpful for visitors (Chang et al., 2012). Regarding this, respondents proposed graphic-based information to be used more as interpretative materials in the museums. They also affirmed that their needs in technology characteristics would be met by creating immersion and stimulating both enjoyment and creativity. With a mean score of 4.07, most visitors professed that text-based materials explained the museum collections ineffectively. As complained by most interviewees, the captions were either long or sometimes displayed similar content to those exhibited on the touchscreens. Alwi and McKay (2013) discovered that multimedia of both text and graphicbased presentation offers better museum learning for verbalisers. This aligns with two of their top three selections on interactive technology, including virtual reality and multi-sensory technology. 


\section{Museum Experience Scale}

Museum Experience Scale (MES) integrates visitors' feedback on the overall museum experience with a better insight on all aspects, including engagement, emotional connection, meaningful experience and learning outcomes.

\section{i. Engagement}

When measuring engagement, various characteristics are included, such as enjoyment, inspiration, creativity, involvement, and attention. The following six questions were constructed specifically in acquiring details on each of the characteristics.

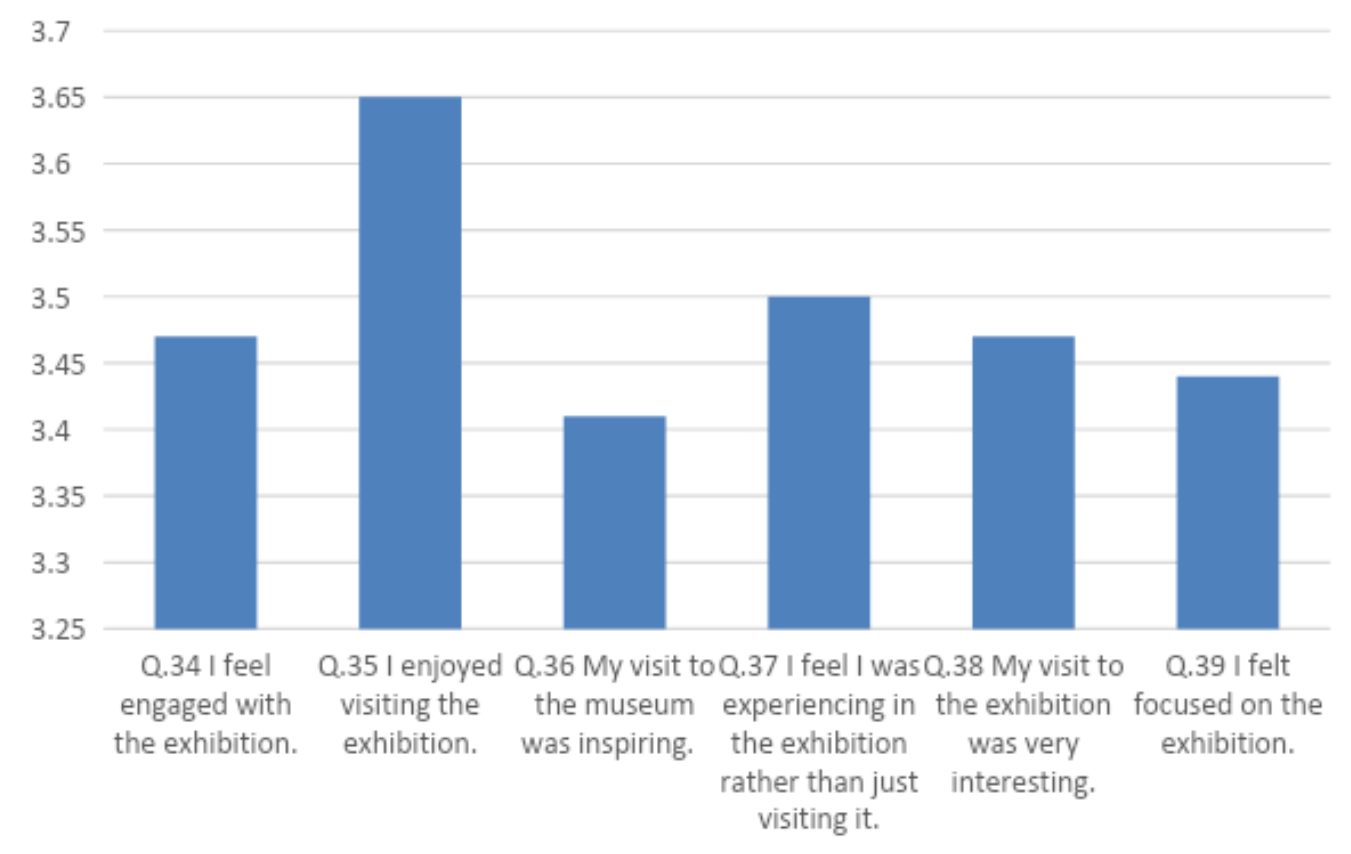

Figure 5. The mean score of visitors' overall museum experience in terms of engagement. Note: 5-point Likert Scale (1= Strongly Disagree, 2= Disagree, 3= Neutral, 4= Agree, 5= Strongly Agree).

Question 34 measured direct engagement and the mean score of 3.47 indicated a good visitors' engagement. The rest of the scores ranged between 3.41-3.65. They signalled that the museum visits were interesting, enjoyable and inspiring, but were yet to reach the engagement level that fully grasp visitors' attention. The findings concluded that most museum contents were enjoyable, but not ideally engaging, inspiring and exciting. This was especially the case for those international tourists who were unable to relate to the objects/exhibitions without interpretative materials to explain the collections. Since the museums' existence in Brunei is more recognisable among researchers, this means social experiences are unlikely to occur (Waltl, 2006). Hence, children and tourists, who require more effort in interaction, tend to be neglected.

\section{ii. Emotional Connection}

This aspect relates to one's immersion, self-contained experiences, and object experiences. A person's emotions can be triggered by tapping into his memory to trigger flashback moments. It is important to note that all museum collections can establish visitors' emotional connection through profound storytelling. 
3.6

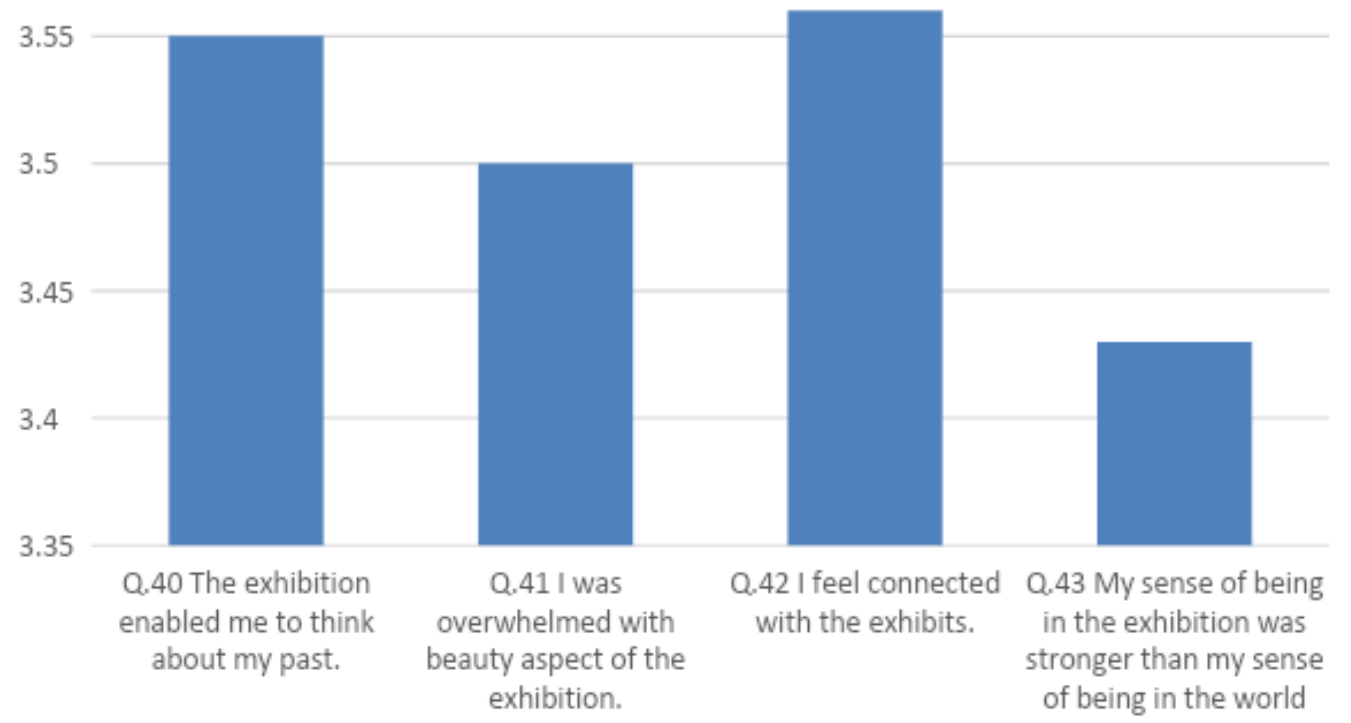

Figure 6. The mean score of visitors' overall museum experience in terms of emotional connection.

Note: 5 -point Likert Scale (1= Strongly Disagree, $2=$ Disagree, $3=$ Neutral, $4=$ Agree, $5=$ Strongly Agree).

Questions 40 and 42 measured introspective experiences, whereby most respondents agreed in general that the exhibitions successfully made them think about their past and that they felt connected with the exhibits. This shows that the museum collections in the exhibition had managed to stimulate visitors into reminiscing about their past to an extent which created a connection with the exhibitions. In the case of Question 41, some respondents agreed to "I was overwhelmed with the beauty aspect of the exhibition", demonstrating that museum visitors in Brunei are somewhat affected through object experiences. Similarly, responses to Question 43, where some respondents approved that their sense of being in the exhibition was stronger than their sense of being in the world, indicating that visitors felt slightly immersed during the visit.

The findings to this aspect indicated introspective experiences rather than object experiences triggered emotional connections. Essentially, the museum contents made visitors nostalgic about their past and, at the same time, managed to establish a sense of connection with the exhibitions. In comparison to object experience, only some visitors claimed to be affected by the aesthetics of exhibitions and, hence, the creation of slight immersion. Certain collections only stimulated their emotional connection at certain museums which were associated with their memories. Bitner supported this statement, asserting that environmental settings typically influenced emotional responses (as cited in Packer, 2008). Through curated museum space, this enables visitors to imagine and connect easily, as it heightens the introspective experiences even more with private feeling and soothing environment (Pekarik et al.,1999).

\section{iii. Meaningful Experience}

Like emotional connection, meaningful experience measures feature such as object experiences, involvement and effort, knowledge and understanding, and self-contained experiences. It involves enabling a visitor to feel appreciation towards museum collections and 
to value the items even more. Thus, one may easily have a meaningful experience when he develops an attachment towards the artefacts. Five questions were established in an attempt to explore visitors' extent of meaningful experience.

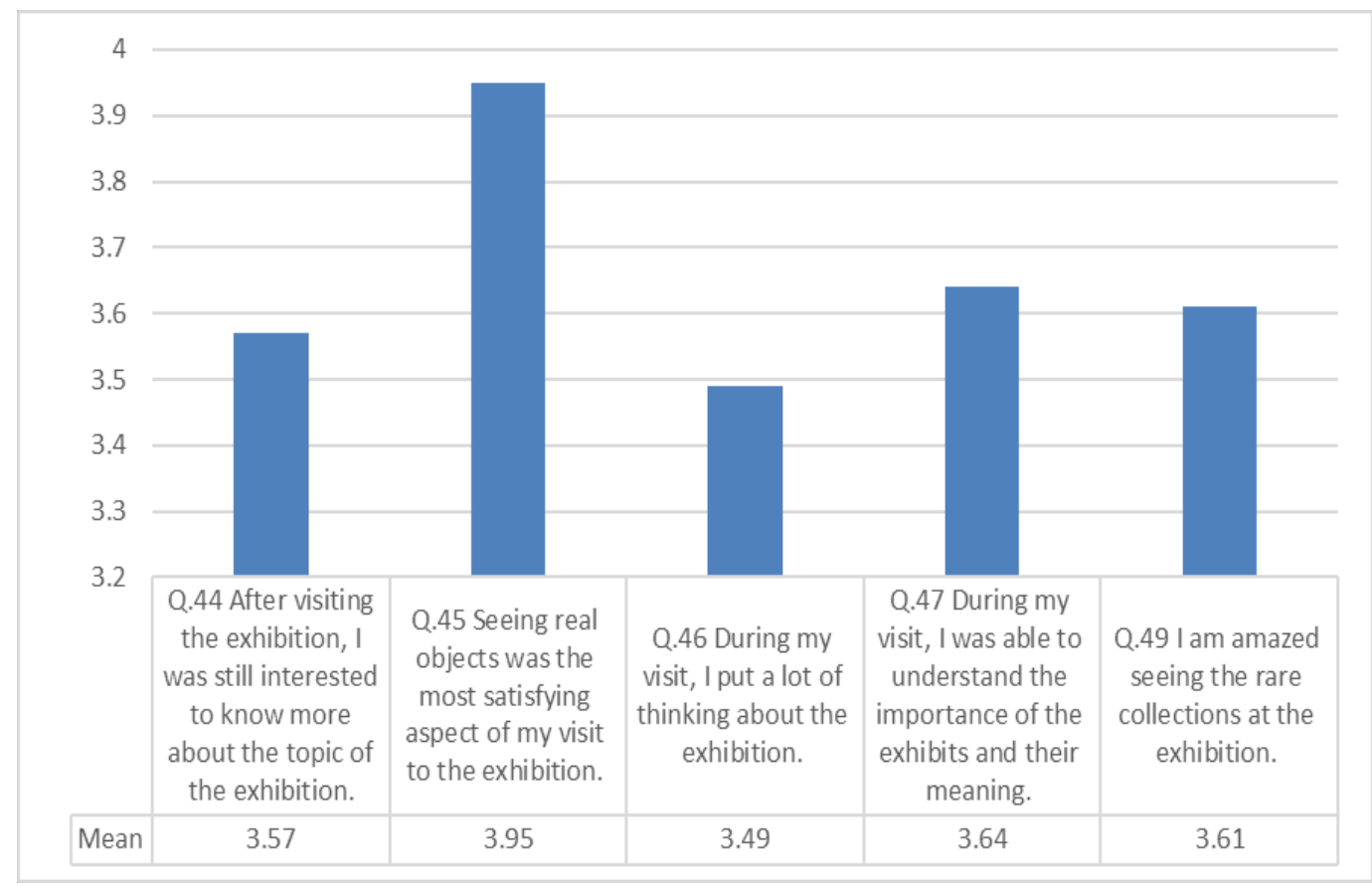

Figure 7. The mean score of visitors' overall museum experience in terms of meaningful experience.

Note: 5-point Likert Scale (1= Strongly Disagree, 2= Agree, 3= Neutral, 4= Disagree, 5= Strongly Disagree).

In general, exhibitions managed to create a feeling of curiosity and interest in wanting to know more about the topic of the exhibition. It is believed that, with even just a small amount of knowledge gained from an exhibition, this would still produce a meaningful experience for visitors (Sienkiewicz, 2015). The majority of the respondents admitted that looking at real objects ultimately satisfied them (3.64), and they also claimed that rare collections would impress them (3.61). This signified an increase in visitors feeling appreciation, especially when artefacts were displayed in the exhibition. As past research has clearly defined, the process with which to achieve meaningful experience in museums would be a mixture of discovering facts and witnessing objects (Packer, 2008; Sienkiewicz, 2015; Dizon, 2017).

Meanwhile, Questions 46 and 47 aimed to assess visitors' introspective experience. The findings suggest that visitors did understand the importance of the artefacts based on their prior experience, while there were visitors who thought deeply about the collections and developed different perceptions due to a lack of engaging storytelling. Introspective experience, on the other hand, was highlighted by Packer (2008), who stated that introspective experience can't occur unless associated with two other experiences, object and cognitive experiences.

\section{iv. Learning Outcomes}

When it comes to learning outcomes, a person's knowledge and understanding and cognitive experiences must be considered. In this context, attaining information and utilising it into reallife situations seemed to be one of the ways for evaluating learning outcomes. Therefore, to 
understand visitors' feedback on the information-rich displays, six (6) questions were presented as listed in Figure 8.

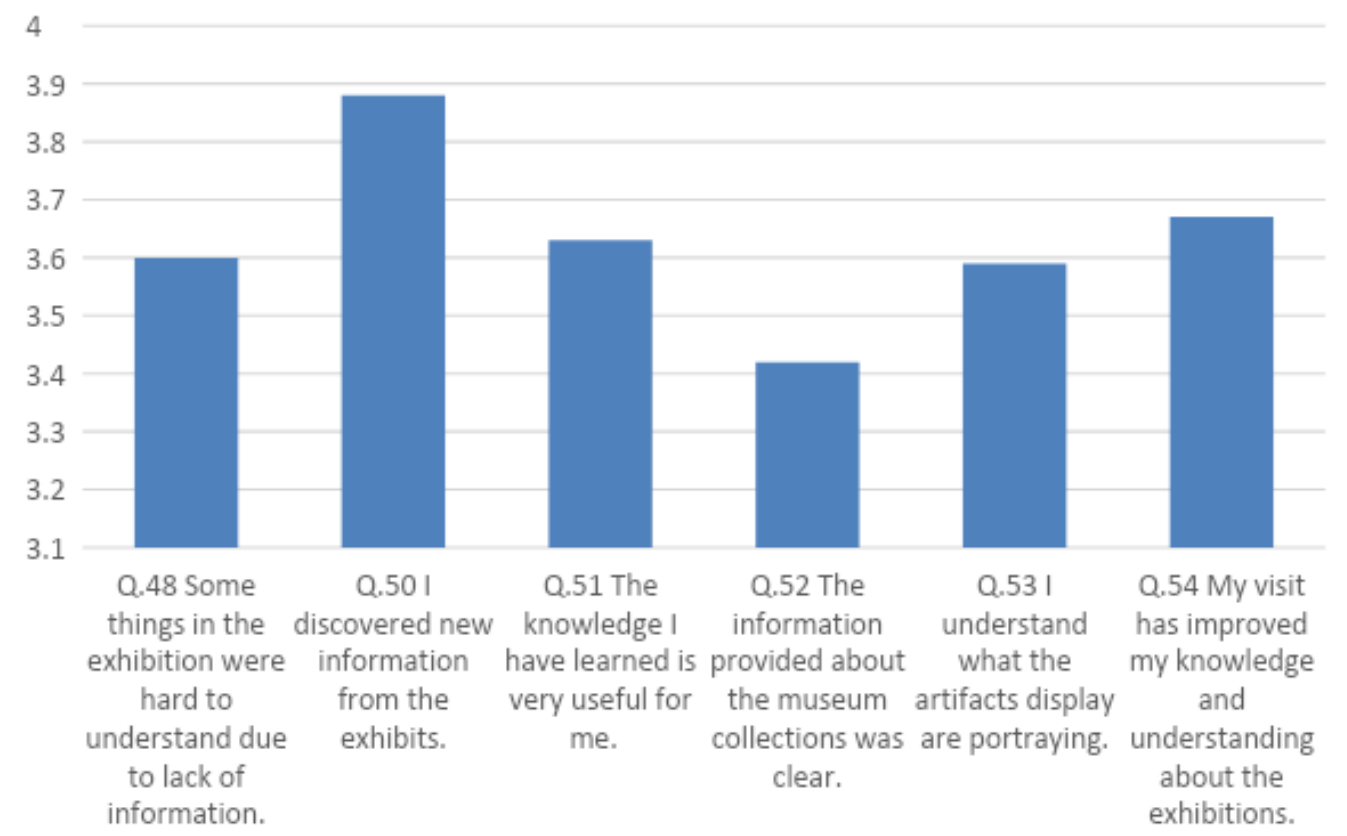

Figure 8. The mean score of visitors' overall museum experience in terms of learning outcomes. Note: 5-point Likert Scale (1=Strongly Disagree, 2= Disagree, 3= Neutral, 4= Agree, 5= Strongly Agree).

When asked about the presentation of information, it was concluded that, on the whole, it was understandable (Question 53). Still, some respondents claimed that some artefacts in the exhibitions were difficult to understand due to a lack of information (Question 48), indicating that some artefacts were well presented and some were not. In Question 50, the majority of respondents acknowledged their discovery of new information from the exhibition and, in response to this, visitors were tested on their cognitive experience through Questions 51 and 54. As observed from both questions, some respondents declared their visit to have improved their knowledge and understanding of the exhibition (Question 54), but the knowledge they gained may not prove entirely useful. This could be because the partial information presented was general knowledge that most Bruneians may already have known.

Based on this finding, it can be concluded that two components of MES (meaningful experience and learning outcomes) highly affected the respondents' visitor experience. This justifies the claims made by museum experts who strongly stress their role in educating potential visitors through continuous briefings to school students and their efforts to exhibit the artefacts as informative as possible. The strategy confirms the discovery made by Memişoğlu and Kamçi (2013), in which school students strongly believed that museums were helpful in giving them the best learning environments, particularly in the area of social study.

Most visitors claimed to have gained new information during their visit and acknowledged that exhibitions had improved their knowledge and understanding, but, surprisingly, these were less useful to real-life situations. With museums strongly promoting the learning experience, some respondents agreed that their cognitive experiences had been enhanced through the contextual information. Pekarik et al. (1999) also discovered that this type of experience was commonly found in didactic exhibitions specifically engaged passive visitors (as cited in Ahmad 
et al., 2014). Again, this concludes the need to employ a visitor-centric approach in order to produce fruitful learning outcomes.

\section{v. Exhibition Design}

Figure 9 shows respondents' satisfaction levels towards museum concepts and their offerings. Of the respondents, $38.2 \%$ pointed out the lack of engaging activities and stimulating exhibition design. Due to the current museum approach, which is not visitor-centric, visitor experience has become partially pleasing, especially when the presentation of museum collections does not complement visitors' interests, prior knowledge, and past visits. This is true because individual background (i.e. visitors' prior knowledge and experience), collective background (i.e. visitors' culture and attitude), and tangible background (i.e. exhibition of artefacts and museum space) are important aspects in measuring the museum experience (Falk \& Dierking, 1992).

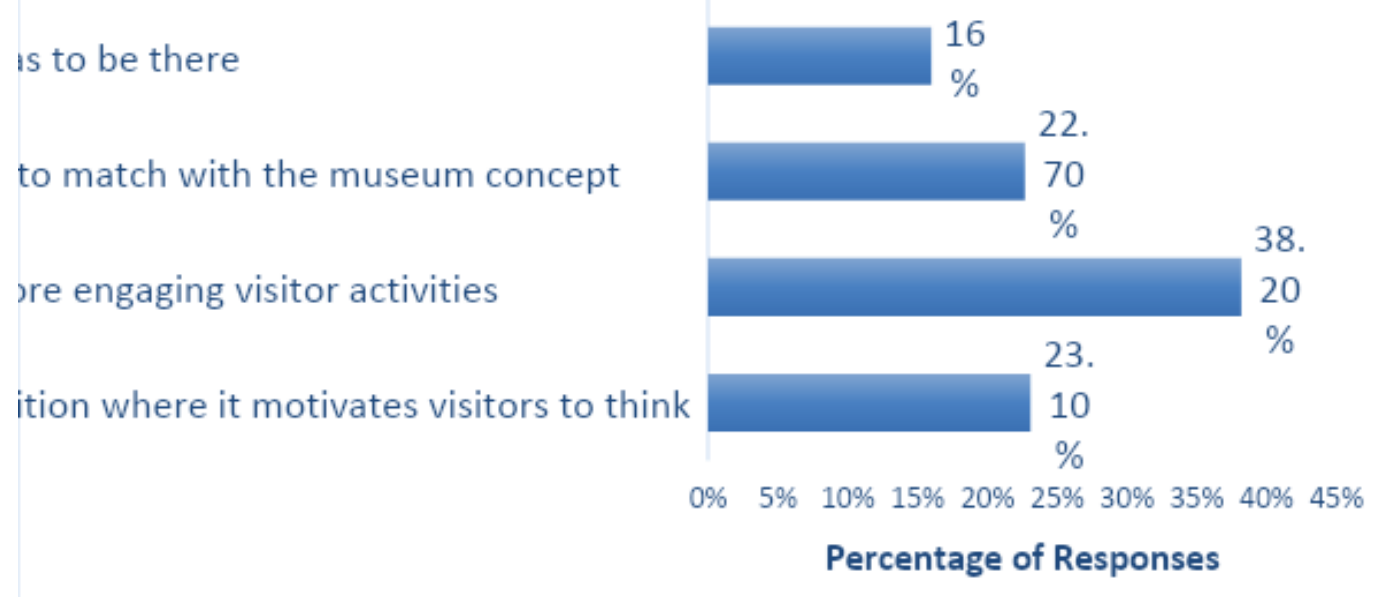

Figure 9. Visitors' opinions towards the current museum exhibition design.

\section{Overall Satisfaction}

The findings revealed that, on average, the respondents only felt slightly satisfied with the overall museum experience. This is particularly true in terms of their experience with regard to exhibition design, technology usage (kiosks, multi-touch tables, audio-visual guides), and information provided. The visits to Brunei museums were not highly satisfactory for visitors because their different needs were ignored. Obviously, the mean score of 2.77 (refer to Figure 10) indicated respondents' dissatisfaction with the current museum collections. The outdated collections, along with the unattractive storytelling, contributed to visitors' loss of interest in the overall attraction of museums. Visitors' attention can only be attracted through the display of interestingly authentic and uncommon collections associated with profound storytelling (Sirová, 2017). 


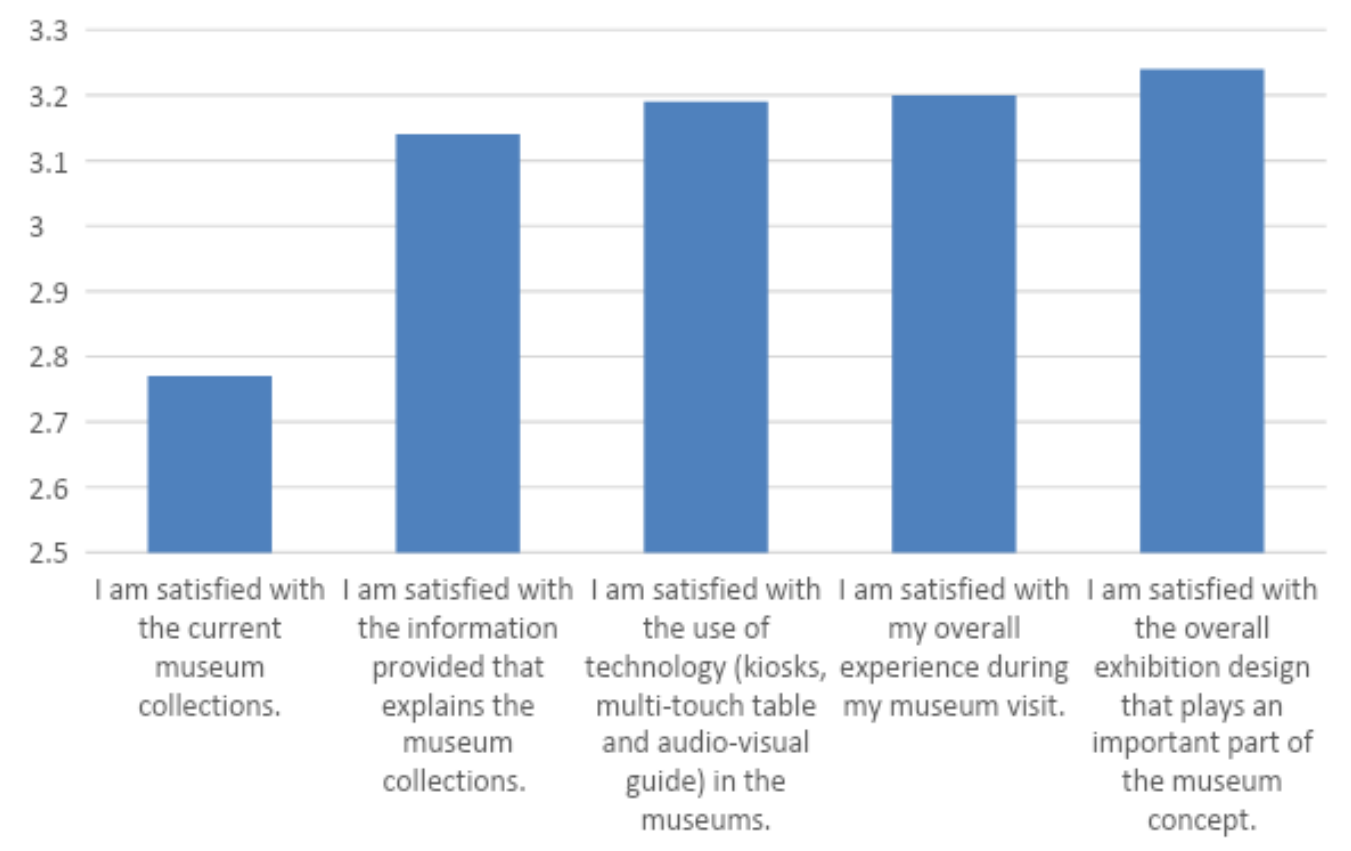

Figure 10. Visitors' level of satisfaction towards overall museum approach.

Note: 5-point Likert Scale (1=Strongly Disagree, 2= Disagree, 3= Neutral, 4= Agree, 5= Strongly Agree).

Additionally, since the technology provided offered no personalisation, it continued to degrade the visitors' satisfaction. It is unfortunate that the museums neglected different visitors' motivations and expectations, especially when the purpose of a visit was to obtain new knowledge in relation to history, culture, and the artefacts (Reino et al., 2007; Ryan \& Trinh, 2013).

\section{Discussion and Conclusion}

This study aimed to understand visitors' experiences and their views about interactive technology in museums in terms of satisfaction. Specifically, the findings of the study provide evidence that museums have acquired average qualities in the digital era. Despite the existing technology, such as touchscreen and audio-visual guides, the overall museum experience was observed to be marginally satisfying. As each aspect of MES scored an average mean score of 3 , this evidently shows that the performance of Brunei's museums could not yet be considered sufficient.This study's findings underline the dominance of interactive technology in the context of generating engagement and meaningful experience. Advanced technology encapsulates experiences of augmented reality, virtual reality, simulations and similar digital elements, thus providing visitors with an experience detached from time and space (Sökmen et al., 2020). Thus, Brunei's museums should actively adopt digitalisation to become competitive and consider investing in technology to remain sustainable.

The findings also reveal that museum management fails to design their exhibitions effectively, with missing engaging activities and interactive technology components. History museums should emphasise artefact presentations and environment-exhibition to allow visitors to look at the rare and real objects and, simultaneously, to develop their emotions and immersive experiences (Pekarik et al., 1999). This would further stimulate visitors' cognitive experience and, in return, enable them to attain new information (Sirová, 2017). History museums could have added more engaging activities for visitors to augment value transmission, instead of 
having more items surrounded by an abundance of contextual information. According to Hernández (2017), designing exhibitions as interactive will surely cover the shortcomings of museums, such as the deficiency in delivering museum contents. Moreover, museum managers should strive to find creative ways for their guests to simultaneously involve themselves in production and consumption.

This study finds that Brunei's museums should focus on transforming themselves into a musthave quality, in terms of exhibiting museum contents in at least three stages, as described by Hudson (1997). Firstly, to assure satisfaction and repeat visits from the public, museums should consider the different types of visitors, in terms of age, social background and learning styles. From this it will allow museums to realise visitors' needs, thus enabling them to produce personalised and effective presentations of artefacts for them. Secondly, the museum collections must be interesting for the visitors to an extent that museums are perceived as beneficial and worth making a visit. This is to be achieved with technology, especially those that fall into the advanced and interactive categories. Mainly, since the younger generation is now focused on experience instead of object observation as their way of understanding and valuing artefacts, technology integration should be attempted to exhibit artefacts in a much more engaging manner. In other words, museums must change their strategy from "expert-centric" to "visitor-centric" (Stogner, 2009).

Thirdly, museums should establish a welcoming environment as a suitable atmosphere for both leisure and educational activities as a go-to destination. Museums should respond to inevitable change by becoming visitor-centered (Hellgren, 2015) and continue to revolutionise their services (Abuamoud et al., 2018). Thus, when these characteristics are practised, surely museum experience will improve and, therefore, repeat visitation will be more likely to happen. As sustainability parameters should be enforced in all tourisms, a museum as one of heritage destinations is to be included taking into account the level of resources, capacities, and impacts it brings to visitors (Giampiccoli, Mtapuri \& Dłużewska, 2020).

\section{Limitations}

The results of the present study should be evaluated considering certain limitations. The primary limitation of the study is that only three museums exhibiting contemporary characteristics in Brunei were examined. Several museums in other parts of the country may have contemporary characteristics or occasionally display contemporary environments. It is possible that the inclusion of other museums in other parts of the country may strengthen the findings of this study. Although quantitative studies allow researchers to understand museum visitors' perceptions, experience, and satisfaction, the need for comprehensive studies is apparent. Therefore, future research should develop and validate a mixed data collection method with which to enrich our understanding of contemporary museums. Moreover, this study is limited to museum visitors as participants, and their accounts of museum experience serve merely as a starting point for further research into the effects of contemporary conditions on museum marketing. However, it is essential to understand how managers evaluate these practices and how they position the museums they manage. Therefore, continued examination of managers' perspectives regarding contemporary museum practices has the potential to deepen our understanding of contemporary museums.

\section{Corresponding Author}

Salamiah A Jamal

Faculty of Hospitality and Tourism Management, Universiti Teknologi MARA, Malaysia 
Email: drsalamiah@uitm.edu.my

\section{References}

Abuamoud, l., Ibrahim, A., \& Alrousan, R. (2018). Measuring tourists' satisfaction and loyalty: A perception approach. Quality management journal. 25(2), 101-107.

Adam, M., Zheng, S., \& Woodcock, A. (2005). Surprise and illusion: Design strategies for interactive museum exhibits. In Ciolfi, L., Cooke, M., Hall, T. Bannon, L. J. \& Oliva, S. (Eds.). Re-thinking technology in museums: Towards a new understanding of people's experience in museums. 18-25. Ireland: University of Limerick.

Ahlamo, E. (2013). Interactive exhibitions. The use of interactivity in educational exhibitions. (Master's thesis, Tampere University of Applied Science), Retrieved from https://www.theseus.fi/bitstream/handle/10024/57802/Ahlamo_EevaKaisa. pdf? sequence $=1 \&$ isAllowed $=y$.

Ahmad, S., Abbas, M. Y., Taib, M. Z. M., \& Masri, M. (2014). Museum Exhibition Design: Communication of meaning and the shaping of knowledge. Procedia-Social and Behavioral Sciences, 153, 254-265.

Alwi, A., \& McKay, E. (2013). Understanding children's museum learning from multimedia instruction. IADIS International Conference e-Learning. 25-32. Retrieved from https://files.eric.ed.gov/fulltext/ED562303.pdf.

Budhwar, K. (2017). The role of technology in education. International journal of engineering applied sciences and technology. 2(8), 55-57.

Cerquetti, M. (2016). More is better! Current issues and challenges for museum audience development: A literature review. Journal of Cultural Management \& Policy, 6(1), 30-43.

Chang, C. C., Yan, C. F., \& Tseng, J. S. (2012). Perceived convenience in an extended technology acceptance model: Mobile technology and English learning for college students. Australasian Journal of Educational Technology. 28(5), 809-826.

Davidson, L., \& Sibley, P. (2011). Audiences at the "new" museum: Visitor commitment, diversity and leisure at the Museum of New Zealand Te Papa Tongarewa. Visitor Studies, 14(2), 176-194.

Davis, F. D. (1993). User acceptance of information technology: system characteristics, user perceptions and behavioral impacts. International Journal Man-Machine Studies. 38, 475-487.

Denzin, N. K., \& Lincoln, Y. S. (Eds.). (2011). The Sage handbook of qualitative research. Sage.

Dizon, C. A. (2017). Journey to the centre of the museum: Cognitive, object and introspective user experiences in a design museum. (Master's thesis, Lund University).

Falk, J., \& Dierking, L. (1992). Redefining the museum experience: The interactive experience model. 172-176. Retrieved from http://www.informalscience.org/sites/default/files/VSA-a0a5b9-a_5730.pdf.

Giampiccoli, A., Mtapuri, O., \& Dłużewska, A. (2020). Investigating the intersection between sustainable tourism and community-based tourism. Tourism: An International Interdisciplinary Journal, 68 (4), 415-433. https://doi.org/10.37741/t.68.4.4

Gilmore, A., \& Rentschler, R. (2002). Changes in museum management: A custodial or marketing emphasis? Journal of Management Development, 21(10), 745-760.

Hardy, M. (2004). Summarizing distributions. In Hardy, M. \& Bryman, A. (Eds.). Handbook of data analysis. 35-43. Wiltshire: SAGE Publications, Inc.

Hashim, A. F., Taib, M. Z., \& Alias, A. (2014). The integration of interactive display method and heritage exhibition at museum. Procedia-Social and Behavioral Sciences. 153, 308-316. 
Hellgren, R. K. (2015). Designing for museum relevancy: improving innovation and adaptability in museum management with design thinking. (Master's thesis, Kent State University). Retrieved from https://etd.ohiolink.edu/!etd.send_file?accession=kent1429521944\&disposition=inlin

Hernández, S. R. (2017). Vapriiki case: design and evaluation of an interactive mixed-reality museum exhibit. (Master's thesis, University of Tampere). Retrieved from https://pdfs.semanticscholar.org/61ca/77ac99f969922b49b79139d6dc8d595b6a33.pd $\mathrm{f}$.

Hudson, K. (1997). The concept of public quality in museums. In Negri, M., Niccolucci, F. \& Sani, M. (Eds.). Quality in museums. 18-21. Retrieved from http://www.culturalinformatics.org.uk/sites/culturalinformatics.org.uk/files/quality.pd $f$.

Ibrahim, F., \& Zainin, N. M. (2021). Exploring the Technological Impacts: The Case of Museums in Brunei Darussalam, International Journal of Tourism and Hospitality Management in the Digital Age (IJTHMDA), IGI Global, 5(1), 1-18.

Jafari, A., Taheri, B., \& Vom Lehn, D. (2013). Cultural consumption, interactive sociality, and the museum. Journal of Marketing Management, 29(15-16), 1729-1752.

Komarac, T., Ozretic-Dosen, D., \& Skare, V. (2017) Understanding competition and service offer in museum marketing. Academia Revista Latinoamericana de Administración, 30(2), 215-230.

Lehn, D., \& Heath, C. (2005). Accounting for new technology in museum exhibitions. International journal of arts management. 7(3), 11-21.

Memişoğlu, H., \& Kamçi, S. (2013). Museum of social studies in education students' attitudes and views. International Journal on New Trends in Education and Their Implications. 4(3), 121-138. Retrieved from http://www.ijonte.org/FileUpload/ks63207/File/14.memisoglu.pdf.

Not, E., \& Petrelli, D. (2018). Blending customization, context-awareness and adaptivity for personalized tangible interaction in cultural heritage. International Journal of HumanComputer Studies.

O'Mahony, C. (2013). Working group 'New trends in museums of the 21st century.' Survey 2012 "Key trends in museums." The learning museum. 61-84. Retrieved from http://online.ibc.regione.emilia-romagna.it/I/libri/pdf/LEM7th-report-new-trends-inmuseums-of-the-21st-century.pdf.

Othman, M. K. (2012). Measuring visitors' experiences with mobile guide technology in cultural spaces. (PhD dissertation, University of York)

Packer, J. (2008). Beyond learning: Exploring visitors' perceptions of the value and benefits of museum experiences. 51(1), 33-54.

Pekarik, A., Doering, Z., \& Karns, D. (1999). Exploring satisfying experiences in museums. Curator: The museum journal. 42(2), 152-173.

Pop, I. L. \& Borza, A. (2016). Technological innovations in museums as a source of competitive advantage. The 2nd International Scientific Conference SAMRO 2016. 398-405.

Pulh, M., \& Mencarelli, R. (2015). Web 2.0: Is the museum-visitor relationship being redefined? International Journal of Arts Management, 18(1), 43-51.

Reino, S., Mitsche, N., \& Frew, A. (2007). The contribution of technology-based heritage interpretation to the visitor satisfaction in museums. Information and communication technologies in tourism 2007. 341-352. Vienna: Springer. 
Rentschler, R., \& Gilmore, A. (2002). Museums: Discovering services marketing. International Journal of Arts Management, 5(1), 62-72.

Ryan, C., \& Trinh, T. (2013). Museums, exhibits and visitor satisfaction: A study of the Cham Museum, Danang, Vietnam. Journal of tourism and cultural change. 11(4), 239-263.

Scoffield, S., \& Liu, J. (2014). Online marketing communications and the postmodern consumer in the museum context. Retrieved 2 December, 2020, from Cambridge University, Cambridge Business \& Economics Conference (CBEC) web site: http://www.gcbe.us/2014_CBEC/data/Susan\%20Scoffield,\%20Jie\%20Liu.pdf.

Sienkiewicz, N. (2015). Creating meaningful experiences in art museums. In Anderson, D., Cosson, A., \& McIntosh, L. (Eds.), Research informing the practice of museum educators. 231-245. Rotterdam: Sense Publishers.

Sirová, K. (2017). Museum exhibition as an educational medium. Apheleia - Integrated cultural landscape management for local and global sustainability intensive program 2017. Retrieved from

http://www.apheleiaproject.org/apheleia/upload2017/Museum\%20Exhibition\%20as\% 20an\%20educational\%20medium.pdf.

Sökmen, S., Yolal, M., \& Özel, Ç. H. (2020). Does Museum Marketing Meet Postmodern Conditions? Advances in Hospitality and Tourism Research (AHTR), 8(2), 288-313.

Stogner, M. (2009). The media-enhanced museum experience: debating the use of media technology in cultural exhibitions. Retrieved from http://web.mit.edu/commforum/legacy/mit6/papers/Stogner.pdf.

Stogner, M. (2011). The immersive cultural museum experience - creating context and story with new media technology. The international journal of the inclusive museum. 3(3), 118130.

Taheri, B., O'Gorman, K., \& Baxter, I. (2016). Contemporary issues in museums and heritage marketing management: Introduction to the special issue. Journal of Marketing Management, 32(15-16), 1387-1391.

Thomas, S. (1999). Interactive media and the museum experience. Archives and museum informatics. 164-168.

Vaz, R., Fernandes, P. O., \& Veiga, A. (2018). Interactive technologies in museums: How digital installations and media are enhancing the visitors' experience. In Rodrigues. J., Ramos, C., Cardoso, P., \& Henriques, C. (2018). Handbook of research on technological developments for cultural heritage and eTourism applications. 30-53. Hershey: IGI Global.

Waltl, C. (2006). Museums for visitors: Audience development - A crucial role for successful museum management strategies. Intercom 2006 conference paper. Retrieved from http://intercom.museum/documents/1-4Waltl.pdf. 